\title{
Effects of nutrients supply on milk yield, composition, and enteric methane gas emissions from smallholder dairy farms in Rwanda
}

\author{
Jean de Dieu Ayabagabo ${ }^{1,2 *}$, Paul Anthans Onjoro ${ }^{2}$, Perminus Karubiu Migwi ${ }^{2}$ and Marie \\ Christine Dusingize ${ }^{1}$
}

\author{
${ }^{1}$ Department of Animal production, School of Animal science and veterinary medicine, University of Rwanda, Rwanda. \\ 2Department of Animal Science, Faculty of Agriculture, Egerton University, Kenya. \\ *Corresponding author. Email: ayabagabojean87@gmail.com
}

Copyright (C) 2021 Ayabagabo et al. This article remains permanently open access under the terms of the Creative Commons Attribution License 4.0, which permits unrestricted use, distribution, and reproduction in any medium, provided the original work is properly cited.

Received 12th April, 2021; Accepted 28th April, 2021

\begin{abstract}
This study investigated the effects of feed on milk yield and quality through feed monitoring and quality assessment, and the consequent enteric methane gas emissions from smallholder dairy farms in drier areas of Rwanda, using the Tier II approach for four seasons in three zones namely; Mayaga and peripheral Bugesera (MPB), Eastern Savanna and Central Bugesera (ESCB), and Eastern plateau (EP). The study was carried out using 186 dairy cows with a mean live weight of $292 \mathrm{Kg}$ in three communal cowsheds. The milk quality analysis was carried out on 418 samples. Data collected were subjected to ANOVA.The dry matter intake was lower $(\mathrm{p}<0.05)$ in the long dry season $(7.24 \mathrm{Kg})$ with the ESCB zone having the highest value of $9.10 \mathrm{Kg}$. The Dry matter digestibility varied between seasons and zones ranging from 52.5 to $56.4 \%$ for seasons and from 51.9 to $57.5 \%$ for zones. The daily protein supply was higher $(p<0.05)$ in the long rain season with $969 \mathrm{~g}$. The mean daily milk production of lactating cows was $5.6 \mathrm{~L}$ with a lower value $(p<0.05)$ during the long dry season $(4.76 \mathrm{~L})$ and MPB zone having the lowest value of $4.65 \mathrm{~L}$. The yearly milk production per cow was $1179 \mathrm{~L}$. The milk fat varied from 3.79 to $5.49 \%$ with a seasonal and zone variation. No variation was observed with milk protein. The seasonal daily methane emission varied from $150 \mathrm{~g}$ for the long dry season to $174 \mathrm{~g}$ for the long rain season $(p<0.05)$. The mean emission factor was $59.4 \mathrm{Kg}$ of methane/year. The methane emission per unit of milk production was lower in EP zone $(46.8 \mathrm{~g} / \mathrm{L})$. Farmers should use high-quality feeds to increase the milk yield and reduce the methane gas produced per unit of milk.
\end{abstract}

Keywords: Footprint, forage, Girinka, Tier II.

\section{INTRODUCTION}

Rwanda's economy is based on agriculture like most of the countries in Africa contributing up to $43 \%$ of the national gross national product (GDP) (National Institute of Statistics of Rwanda (NISR, 2016). Livestock as one of the major components of agriculture contributes up to $12 \%$ of the agricultural GDP with cattle being the main contributor (NISR, 2016). In Rwanda, cattle were targeted and used to reduce the impact of malnutrition through improved milk production and consumption. Programs targeting improved milk production in the dairy sector, such as the
Girinka program, were developed to enhance food security, especially in marginalised families (Rwanda Governance Board (RGB), 2018). The Girinka program consisted of the distribution of dairy cows to poor families. The number of cows distributed under the framework of Girinka program contributed significantly to nearly a double increase in milk production by $89 \%$, from 372,619 $\mathrm{L}$ in 2010 to $706,030 \mathrm{~L}$ in 2015 (RGB, 2018). Despite the positive trend in the dairy sector, farmers face many challenges, mainly lack adequate feed for cattle, that 
impairs milk yield and quality. The milk quantity and quality can be influenced by the nutrition factors as reported in previous research (Arriola et al., 2014; Jensen et al., 2015). These include forage quality, forage concentrate ratio, level and type of dietary fat among others which have an effect on microbial ruminal fermentation. Microbes determine the composition of the milk, including milk protein, milk fat, solid nonfat and milk lactose (BrunLafleur et al., 2010). Studies showed a shortage of feed supply mainly during the dry seaso is a major constraint to increased milk production in Rwanda (Mutimura et al., 2015). In attempt to overcome these feed related challenges, farmers use conventional and nonconventional feedstuffs to meet the daily feed intake but not the nutrients requirement, which can lead to the relative higher methane emission per milk unit (Mutimura et al., 2015, Hammond et al., 2013).

Apart from being a source of food and income, livestock also affects the environment negatively through greenhouse gas production, mainly enteric methane. The contribution of livestock on methane emission in Africa was estimated at over $70 \%$ of African agricultural greenhouse gas (GHG) emissions, and methane gas being the major component (Tubiello et al., 2014). Methane $\left(\mathrm{CH}_{4}\right)$ is a potent gas in terms of global warming with a potential that is 23 times higher than that of carbon dioxide (Loh et al., 2008). Moreover, the enteric methane gas production also represents a loss of gross energy from feed ingested by the ruminant. It is estimated that 2 to $12 \%$ of feed gross energy in ruminants is lost as methane gas and therefore contributes to low efficiency in feed utilization (Johnson and Johnson, 1995). This loss may even be higher during the dry season when a high proportion of daily DM intake is made of feeds containing high levels of cell wall constituents whose digestion in the rumen is associated with acetate type of fermentation that also produces higher quantities of methane. However, increased intake of forage with higher digestibility depresses the amount of $\mathrm{CH}_{4}$ produced per unit of feed consumed (Hammond et al., 2013). The previous studies estimated the methane gas emissions from ruminants in Rwanda using Tier I method for sheep and goats and Tier II for cows (Paul et al., 2018). However, the parameters used for Tier II based largely on estimates by the farmers. The accuracy of farmer estimates can be good in intensive systems but this represents an issue for smallholder livestock systems, where farmers do not keep records.

Hence, there is a lack of information on the current seasonal daily nutrients supply, milk yield, and quality in the Eastern province of Rwanda. Moreover, the effect of these feed supply on milk yield and enteric methane emission is poorly documented. This study, therefore, investigated the effects of feed supply on milk yield and quality and enteric methane gas emission from smallholder dairy farms in drier areas of Rwanda through feed monitoring and quality assessment to improve the accuracy of calculated smallholder dairy cattle emission as compared to the standard IPCC Tier 1 approach and previous estimates.

\section{MATERIALS AND METHODS}

The study was conducted in the three (3) agro-ecological zones, namely, Mayaga and peripheral Bugesera (MPB), Eastern Savanna and Central Bugesera (ESCB), and Eastern plateau (EP) of the Eastern province of Rwanda. The six farms (2 in each AEZ) were used for the study. The study targeted smallholder dairy farm beneficiaries of Girinka program in community cowsheds (CCS). Data was collected from six randomly selected CCS in the Eastern province of Rwanda. Each agroecological zone (AEZ) of the Eastern province of Rwanda was represented by two CCS. Data collection was done four times at approximately two and a half months intervals from August 2018 to June 2019, to approximately coincide with the four seasons reported in the study area. In each CCS, $50 \%$ of cows were randomly selected and their identification recorded. The body condition score was assessed on a scale of 1 to 5 scale (Edmonson et al., 1989). The live weight of cows was estimated from the measured heart girth and body length using Schaeffer's formula (Dingwell et al., 2006; Yan et al., 2009). The information on parity, pregnancy, lactation status, and the stage of lactation was recorded from farmer's recall. The breed was identified from the skin coat color and farmer's recall while age was estimated from dentition (Torell et al., 2003).

\section{Determination of diet quality and seasonal "feed basket"}

The feed was monitored over two (2) weeks in mid-July and November 2018, then in early February and May 2019. August and March are the two dry season months associated with feed scarcity, while October and May are the peaks of the rainy seasons when feeds are more widely available. From each shed, $50 \%$ of cows were randomly selected for feed monitoring in zero-grazing. A $50 \mathrm{Kg}$ spring scale with units of $0.5 \mathrm{Kg}$ was used for weighing feeds given to each selected cow. Refusals were weighed every morning and recorded. The types of feeds offered to cattle during the exercise were identified through observation. Samples of various varieties of feed were pooled separately. For each feeds type, at most five samples were combined to make one sample type. One (1) $\mathrm{Kg}$ was weighted in each sample type and packed in a plastic bag for later chemical analyses. Feed samples were dried at $65^{\circ} \mathrm{C}$ to constant weight and ground to pass through a $1 \mathrm{~mm}$ screen and stored for later analysis. Proximate analysis of feed (Ayabagabo et al., 2020) was done by wet chemistry (Association of Official Agricultural Chemists (AOAC), 1995) for organic matter (OM), ash, Kjeldahl $N(N \times 6.25)$, neutral detergent fiber (NDF), acid 
detergent fiber (ADF), ether extract (EE), and $\mathrm{Ca}$ and $\mathrm{P}$ were determined by atomic absorption spectrophotometer.

The types and total as-fed quantity of each feed resource (Napier grass, Calliandra, cereal stover, etc.) for 14 days per season were recorded for each monitored cow. The dry matter supply of each feed resource was estimated from the feed samples analysis. To determine the daily feed basket composition, the daily proportion of each feedstuff was calculated by dividing the DM quantity in 14 days by 14. From the proportion of feedstuff, the DM, Crude Protein (CP), Neutral and Acid Detergent Fibre (NDF, ADF), Organic Matter (OM), Ether Extract (EE), and energy concentrations were calculated for a daily feed basket per season for each cow. Dry matter digestibility (DMD) was estimated using the equation of Oddy et al. (1983):

DMD $(\% \mathrm{DM})=83.580 .824-\mathrm{ADF}(\% \mathrm{DM})+2.626 \mathrm{~N}(\% \mathrm{DM})$ (1)

$\mathrm{ME}=\mathrm{GE}^{\star} \mathrm{DMM}^{*} \mathrm{CF}(86 \%)$ by Galyean et al., (2016) ----(2)

\section{Milk yield and composition}

Individual morning and evening milk yields of lactating cows were recorded daily using a clear graduated plastic jug. Milk samples from the consecutive evening and morning milking were taken twice during the monitoring period for analysis of composition as a determinant of quality. Milk fat, protein, solids non-fat (SNF), lactose, water content, $\mathrm{pH}$, and density were determined using a Lactoscan SAP standard 1050 (Basic Model: https://lactoscan.com/basic-models-(43,1,3,product=15) verified on 25-04-2021). The quantity of standardized milk called fat and protein corrected milk (FPCM) $(4.0 \%$ fat and $3.3 \%$ protein) was estimated using the formula reported by Tomasula and Nutter (2011) as follow:

$1 \mathrm{Kg} \mathrm{FPCM}=1 \mathrm{Kg}$ milk * $(0.337+0.116$ * Fat $\%+0.06$ * Protein\%)-----------(3)

The milk yield per year was estimated by summing up the seasonal milk production.

\section{Estimation of cattle maintenance and lactation energy}

Metabolizable energy required for maintenance (MERM) and lactation (MERL) were determined for each animal in each season using equations $1.20,1.21$, and $1.12 \mathrm{~A}$ in NRODR (CSIRO, 2007). The MERM was estimated by the following final resulting equation:

$\operatorname{MERM}(\mathrm{MJ} / \mathrm{d})=K * S * M * \frac{\left(0.26 * M L W^{0.75} * \exp (-0.03 * A)\right.}{\left(0.02 * \frac{M}{D}\right)+0.5}$

Where: $\mathrm{K}=1.3$ (intermediate value between that given for
Bos taurus and Bos indicus); $S=1$ for females and castrates, 1.15 for males; $M=1$ ( $0 \%$ milk in diet); $M L W=$ mid-term LW (LW in the middle of the season in $\mathrm{Kg}$ ); $\mathrm{A}=$ age (in years); $M / D=$ Metabolizable-energy content (ME $\mathrm{MJ} / \mathrm{DM} \mathrm{Kg}$ ). M/D = 0.172 * DMD -1.707 (MJ ME/Kg DM); $\mathrm{DMD}=$ Dry Matter Digestibility (\%).

The MERL was calculated using the equation (1.43) given in NRODR (CSIRO, 2007) as:

MERL $=\frac{D M Y * E C M}{\left(0.02 * \frac{M}{D}\right)+0.4}$

Where: $\mathrm{DMY}=$ Daily milk yield $(\mathrm{Kg})$ and $\mathrm{ECM}(\mathrm{MJ} / \mathrm{Kg})=$ Energy content of milk.

Daily milk yield (DMY) was calculated as:

DMY $(\mathrm{L} / \mathrm{d})=\frac{\text { Erecorded daily milk production in a season }}{\text { milking days per season }}$

The ECM was estimated using the formula from NRC, (2001):

ECM $(\mathrm{MJ} / \mathrm{Kg})=\left(0.0929 *\right.$ Fat $\%+0.0547^{*}$ Crude Protein $\%+0.0395 *$ Lactose \%) * $4.184-------(7)$

\section{Daily and yearly methane determination and corresponding energy}

Daily methane production (DMP) was calculated using the equations by Moraes et al. (2014) as follows:

$\mathrm{CH}_{4}=-9.311(1.060)+0.042(0.001) \times \mathrm{GEI}+0.094(0.014)$ x NDF - $0.381(0.092) \times \mathrm{EE}+0.008(0.001) \times \mathrm{BW}+1.621$ (0.119) x MF--------(8) for lactating cows; and

$\mathrm{CH}_{4}=2.880(0.200)+0.053(0.001) \times \mathrm{GEI}-0.190(0.049)$ $x$ EE ------- (9) for non lactating cows

Where: $\mathrm{CH}_{4}=$ Methane emissions $(\mathrm{MJ} / \mathrm{d}) ; \mathrm{GEI}=$ Gross energy intake (MJ/d); NDF = Dietary neutral detergent fiber proportion (\% of dry matter); EE = Dietary ether extract proportion (\% of dry matter); BW = Body Weight $(\mathrm{Kg})$, and $\mathrm{MF}=$ Milk fat $(\%)$.

The estimated $\mathrm{MJ}$ of $\mathrm{CH}_{4}$ is converted to $\mathrm{Kg}$ of $\mathrm{CH}_{4}$ using a conversion factor of $55.58 \mathrm{MJ} \mathrm{Kg}^{-1}$ (EPA, 2014). Annual $\mathrm{CH}_{4}$ production (i.e., the $\mathrm{EF}$ ) for the monitored animal was calculated using the following formula:

$E_{A E Z}=D M P L D *$ days of $L D+D_{+} D_{P R}{ }^{*}$ days of $\mathrm{SR}+$ DMPSD days of SD+ DMPLR ${ }^{*}$ days of $L R$-----(10)

Where: $\mathrm{EF}_{\mathrm{AEZ}}=$ Emission factor in each agro-ecological zone, $\mathrm{LD}=$ Long dry season, $\mathrm{SR}$ = Short rainy season, SD $=$ Short dry season, and LR = Long rainy season. 
The methane emission per milk production was estimated by dividing the total methane emission factor per yearly milk production. Carbon dioxide equivalent was estimated by multiplying the quantity of $\mathrm{CH}_{4}$ by 25 (IPCC, 2007).

\section{Statistical analysis}

Data collected were analyzed using the Statistical Package for Social Scientist (SPSS) software package (SPSS Ver. 16.0, SPSS Inc., Chicago, Illinois). Descriptive statistics (mean and standard error of means (SEM)) were calculated for nutrients supply, DMI, DMD, milk components, DMY, and DMP for each CCS and season. Different AEZ and seasons were compared with the repeated measures and Univariate ANOVA, respectively, followed by Bonferroni's and Tukey honest significant difference tests for comparisons post hoc. A probability level of $\mathrm{p} \leq 0.05$ was considered to be statistically significant. For the milk yield and methane gas analyses, data were subjected to ANOVA using the generalized linear model (GLM). The GLM fitted tested the association of milk production (MP) and methane emissions (DMP) with dry matter digestibility and breeds of animals.

$Y_{i}=\beta_{0}+\beta_{1} X_{1}+\beta_{2} X_{2}+\ldots+\beta n X_{n}+\varepsilon$

Where: $\mathrm{Yi}=\mathrm{MP}, \beta_{0},=$ constant, $\beta_{1-\mathrm{n}}=$ regression parameters, $X_{i}=$ DMP, dry matter digestibility, physiological status (age, stage of lactation, pregnancy, LW) and breeds, $\varepsilon=$ random error effect.

The effect of AEZ and season on DMD and DMP was analyzed using ANOVA fitting seasons and AEZs as factors in a general linear model in the form:

$Y_{i j k}=\mu+T i+\beta_{j}+\varepsilon_{i j}$ with $i=\{1,2,3,4,5,6,7\}$ and $j=\{1,2,3$, 4\}

Where: Yijk= DMP, $\mu=$ overall mean, $\mathrm{T} i=$ level effect of $A E Z, \beta j=l e v e l$ effect of the season ( $R$ or $D)$. $\varepsilon i j=$ random error effect.

\section{RESULTS}

\section{Characteristics of dairy cows}

The study was carried out on 186 dairy cattle representing $50 \%$ of dairy cattle in monitored CCSs. The number per zones was 60,60 , and 66 for MPB, EP, and ESCB zones, respectively. The majority of cows used in this study were aged between 2 to 4 years, with a high variation between AEZ (Table 1). Four (4) types of breeds were identified with the Holstein-Friesian being the most dominant breed $(55.9 \%)$ and the local the least in number $(7.5 \%)$. The lactation numbers varied between 0 and 4 with three (3) lactations dominating. The mean live weight was $292 \mathrm{Kg}$. The seasonal mean live body weight in CCSs, varied from 270 to $311 \mathrm{Kg}$. Most of the cattle were in lactating status throughout the year compared to non-lactating and heifers (Table 1).

\section{Nutrients supply}

The dry matter intake was significantly lower $(p<0.05)$ in the long dry season compared to the other seasons. The ESCB had the highest DMI of $8.10 \mathrm{Kg}(\mathrm{p}<0.05)$, with no significant variation between MPB and EP. The dry matter digestibility (DMD) in the season basket showed a variation between seasons and zones varying from 52.56 to $56.42 \%$ between seasons and from 51.87 to $57.47 \%$ between zones. The DMD was lower $(p<0.05)$ for the dry seasons followed by the short rainy season. The long rain season had the highest $(p<0.05)$ DMD of $56.42 \%$. The DMD was significantly $(p<0.05)$ different among the zones with the MPB zone having the lowest DMD of $51.89 \%$ (Table 2).

The daily protein supply in the seasonal feed basket was significantly $(p<0.05)$ different among seasons, with a high supply of $710.88 \mathrm{~g}$ in the long rain season $(p<0.05)$. ESCB zone had a significantly $(p<0.05)$ lower protein supply of $475.14 \mathrm{~g}$ compared to the two other zones. Neutral detergent fiber (NDF) was significantly $(p<0.05)$ higher for ESCB zone with $4.73 \mathrm{Kg} /$ day compared to MPB and EP zones with 3.35 and $3.22 \mathrm{Kg} /$ day respectively. However, the NDF was higher for the short rainy season. The acid detergent fiber (ADF) followed the same trend as NDF with high value for the short dry season. The ether extract (EE) supply significantly $(p<0.05)$ varied between seasons. It had values between 0.08 for the long dry season and 0.15 $\mathrm{Kg}$ for the long rainy season. However, the moderate variation of $\mathrm{EE}$ among the zones was not significant ( $p>0.05$ ). The mean metabolizable energy supply among the season differed significantly $(p<0.05)$ with $40.05 \mathrm{Kj}$ for the long dry season and $52.80 \mathrm{Kj}$ for the long rainy season. The mean ME supply was different $(p<0.05)$ among the three zones with ESCB zone having the highest value of $51.74 \mathrm{Kj}$ and $40.44 \mathrm{Kj}$ as the lowest for MPB zone. The total metabolizable energy requirements for maintenance (MERM) and metabolizable energy requirements for lactation $(M E R L)$ differed significantly $(p<0.05)$ between the long dry season and short rainy season with 48.38 and $55.80 \mathrm{Kj}$, respectively. MERML was lower $(p<0.05)$ for MPB zone compared to zone EP and ESCB zones (Table 2).

\section{Milk yield and composition}

The mean daily milk production of lactating cows in the study zone was $5.6 \mathrm{~L}$. However, the daily milk production was the lowest $(p<0.05)$ in the long dry season with $4.76 \mathrm{~L}$ compared to the other three seasons with $6.31,5.63$, and 
Table 1. Characteristics of the monitored animals.

\begin{tabular}{|c|c|c|c|c|c|c|c|c|c|c|c|c|}
\hline \multirow{2}{*}{ Categories } & \multicolumn{3}{|c|}{ LD } & \multicolumn{3}{|c|}{ SR } & \multicolumn{3}{|c|}{ SD } & \multicolumn{3}{|c|}{ LR } \\
\hline & MPB & EP & ESCB & MPB & EP & ESCB & MPB & EP & ESCB & MPB & EP & ESCB \\
\hline \multicolumn{13}{|l|}{ Age (years) } \\
\hline$\leq 2$ & 4 & 3 & 7 & - & - & - & - & - & - & - & - & - \\
\hline 2- 4 & 56 & 26 & 19 & - & - & - & - & - & - & - & - & - \\
\hline$>4$ & 0 & 31 & 40 & - & - & - & - & - & - & - & - & - \\
\hline \multicolumn{13}{|l|}{ Breed } \\
\hline L & 10 & 2 & 2 & - & - & - & - & - & - & - & - & - \\
\hline CB & 10 & 16 & 2 & - & - & - & - & - & - & - & - & - \\
\hline$J$ & 6 & 19 & 15 & - & - & - & - & - & - & - & - & - \\
\hline $\mathrm{HF}$ & 34 & 23 & 47 & - & - & - & - & - & - & - & - & - \\
\hline \multicolumn{13}{|c|}{ Lactation number } \\
\hline 0 & 7 & 4 & 8 & - & - & - & - & - & - & - & - & - \\
\hline 1 & 21 & 14 & 6 & - & - & - & - & - & - & - & - & - \\
\hline 2 & 18 & 7 & 14 & - & - & - & - & - & - & - & - & - \\
\hline 3 & 14 & 22 & 30 & - & - & - & - & - & - & - & - & - \\
\hline 4 & 0 & 13 & 8 & - & - & - & - & - & - & - & - & - \\
\hline BW (Kgs) & 270 & 299 & 283 & 283 & 307 & 292 & 280 & 302 & 296 & 290 & 311 & 295 \\
\hline \multicolumn{13}{|l|}{ BCS } \\
\hline 2 & 28 & 5 & 4 & 7 & 0 & 0 & 14 & 3 & 4 & 7 & 0 & 4 \\
\hline 3 & 21 & 44 & 40 & 28 & 24 & 11 & 32 & 36 & 35 & 28 & 42 & 39 \\
\hline 4 & 8 & 11 & 14 & 18 & 32 & 44 & 10 & 20 & 14 & 20 & 16 & 8 \\
\hline 5 & 3 & 0 & 8 & 7 & 4 & 11 & 4 & 1 & 11 & 4 & 2 & 14 \\
\hline \multicolumn{13}{|l|}{ Status } \\
\hline LT & 33 & 38 & 46 & 30 & 46 & 47 & 25 & 46 & 31 & 20 & 36 & 37 \\
\hline NL & 13 & 12 & 11 & 16 & 8 & 10 & 23 & 14 & 23 & 29 & 24 & 24 \\
\hline $\mathrm{H}$ & 14 & 10 & 9 & 14 & 6 & 9 & 12 & 0 & 8 & 10 & 0 & 4 \\
\hline Total & 60 & 60 & 66 & 60 & 60 & 66 & 60 & 60 & 65 & 59 & 60 & 65 \\
\hline
\end{tabular}

LD: Long dry season, SR: Short rainy season, SD: Short dry season, LR: Long rainy season, MPB: Mayaga and peripheral Bugesera, ESCB: Eastern Savanna and Central Bugesera, and EP: Eastern plateau (EP), L: Local, CB:Crossbreed, J: Jersey, HF: Holstein-Friesian, BW: Bodyweight, BCS: Body condition score, LT: lactating, NL: Nonlactating, H: heifer.

$6.10 \mathrm{~L}$ for the short rainy season, short dry season and long rainy season, respectively (Table 3 ). The MPB zone showed a lower daily milk production with $4.65 \mathrm{~L}$ compared to 6.20 and $5.90 \mathrm{~L}$ for EP and ESCB zones respectively. The yearly milk production per cow was $1179.40 \mathrm{~L}$ and followed the same trend with the MPB zone having the lowest production $(771.33 \mathrm{~L})$ compared to the other two zones with 1427.10 and $1325.10 \mathrm{~L}$ for EP and ESCB zones respectively (Table 4 ). The milk fat varied from 3.93 to $4.87 \%$ for zones. EP zone had a significantly $(p<0.05)$ lower butterfat content value compared to the remaining two zones. The short dry season showed the highest $(p<0.05)$ value of $5.49 \%$ compared to other seasons that showed a moderate variation. The mean protein content varied from 3.19 and 3.17 to 3.26 and $3.27 \%$ for zones and season respectively with no significant variation neither with season nor zones. The lactose content was lower in MPB zone (4.67\%) compared to 4.92 and $4.85 \%$ respectively for EP zone and ESCB zones. However, no significant $(p>0.05)$ lactose content variation was observed among seasons. The SNF did not show any significant $(p>0.05)$ variation neither with season nor with zones. It varied from 8.72 to $8.92 \%$ for zones and from 8.69 to $8.94 \%$ for seasons (Table 5 ).

\section{Methane emission}

The seasonal daily methane emission varied from 145.59 to $177.36 \mathrm{~g}$ with the short dry season having the highest 
Table 2. Daily nutrients supply and daily metabolizable energy requirements (MER, MJ/d) for maintenance (MERM) and lactation (MERL) across seasons and AEZ.

\begin{tabular}{|c|c|c|c|c|c|c|c|c|}
\hline Parameters & DM $(\mathrm{Kg})$ & DMD (\%) & Protein (g) & NDF $(\mathrm{Kg})$ & ADF $(\mathrm{Kg})$ & $\mathrm{EE}(\mathrm{Kg})$ & ME $(\mathrm{Kj})$ & $M E_{M+M} M E_{L}(K j)$ \\
\hline \multicolumn{9}{|l|}{ Season } \\
\hline LD & 5.41 & $52.83^{1}$ & $374.58^{1}$ & $3.72^{1}$ & $2.22^{1}$ & $0.078^{1}$ & $40.05^{1}$ & $48.38^{1}$ \\
\hline SEM & 0.136 & 0.239 & 8.91 & 0.113 & 0.059 & 0.002 & 0.97 & 1.26 \\
\hline SR & 6.10 & $54.72^{2}$ & $507.58^{2}$ & $3.99^{2}$ & $2.42^{2}$ & $0.107^{2}$ & $48.19^{2}$ & $55.97^{2}$ \\
\hline SEM & 0.123 & 0.278 & 14.57 & 0.108 & 0.055 & 0.003 & 0.82 & 1.55 \\
\hline SD & $5.93^{2}$ & $52.56^{3}$ & $493.39^{2}$ & $3.94^{12}$ & $2.48^{2}$ & $0.109^{2}$ & $44.75^{3}$ & $51.55^{1}$ \\
\hline SEM & 0.120 & 0.164 & 8.99 & 0.088 & 0.052 & 0.003 & 0.80 & 1.59 \\
\hline LR & $6.18^{2}$ & $56.47^{4}$ & $710.88^{3}$ & $3.56^{13}$ & $2.38^{2}$ & $0.15^{3}$ & $52.80^{4}$ & $50.31^{12}$ \\
\hline SEM & 0.095 & 0.170 & 11.12 & 0.048 & 0.035 & 0.002 & 0.58 & 1.60 \\
\hline \multicolumn{9}{|l|}{ AEZ } \\
\hline MPB & $5.40^{\mathrm{a}}$ & $51.87^{\mathrm{a}}$ & $520.213^{a}$ & $3.35^{\mathrm{a}}$ & $2.38^{\mathrm{a}}$ & $0.11^{\mathrm{a}}$ & $40.44^{\mathrm{a}}$ & $46.02^{\mathrm{a}}$ \\
\hline SEM & 0.135 & 0.111 & 12.45 & 0.081 & 0.054 & 0.003 & 0.85 & 1.64 \\
\hline $\mathrm{EP}$ & $5.49^{a}$ & $57.47^{b}$ & $574.12^{\mathrm{a}}$ & $3.22^{\mathrm{a}}$ & $2.00^{\mathrm{b}}$ & $0.11^{a}$ & $46.62^{b}$ & $54.11^{b}$ \\
\hline SEM & 0.135 & 0.109 & 12.45 & 0.080 & 0.053 & 0.003 & 0.84 & 1.61 \\
\hline ESCB & $6.741^{\mathrm{b}}$ & $53.09^{c}$ & $475.14^{b}$ & $4.73^{b}$ & $2.71^{\mathrm{c}}$ & $0.11^{\mathrm{a}}$ & $51.74^{\mathrm{c}}$ & $54.18^{b}$ \\
\hline SEM & 0.129 & 0.106 & 11.87 & 0.076 & 0.051 & 0.002 & 0.81 & 1.56 \\
\hline \multicolumn{9}{|l|}{ Overall mean } \\
\hline Overall & 5.88 & 54.15 & 523.16 & 3.77 & 2.362 & 0.11 & 46.27 & 51.44 \\
\hline SEM & 0.07 & 0.06 & 7.08 & 0.046 & 0.03 & 0.0 & 0.48 & 0.93 \\
\hline
\end{tabular}

$a, b, c$ Overall means on the same column with different superscripts differ significantly $(p<0.05){ }^{1,2,3}$ Overall means on the same column with different superscripts differ significantly $(p<0.05)$. Number of observations: $M P B=29 ; E P=30 ; E S C B=32$. LD Long dry; $S R=S h o r t$ dry; $S D=S h o r t$ dry; $\mathrm{LR}=$ Long rainy; $\mathrm{SD}^{*}$ : Standard deviation AEZ = Agro-ecological zones, MPB: Mayaga and peripheral Bugesera, EP: Eastern plateau, ESCB: Eastern Savanna and Central Bugesera.

Table 3. Daily milk yield per lactating cow.

\begin{tabular}{lccc}
\hline Parameters & $\mathbf{N}$ & Milk (L/d) & SEM \\
\hline Season & & & \\
Long dry & 119 & $4.76^{\mathrm{a}}$ & 0.161 \\
Short rainy & 123 & $6.31^{\mathrm{b}}$ & 0.168 \\
Short dry & 94 & $5.63^{\mathrm{ab}}$ & 0.164 \\
Long rainy & 92 & $6.10^{\mathrm{b}}$ & 0.238 \\
& & & \\
AEZ & & & \\
MPB & 110 & $4.65^{1}$ & 0.156 \\
EP & 155 & $6.20^{2}$ & 0.144 \\
ESCB & 163 & $5.90^{2}$ & 0.164 \\
& & & \\
Overall mean & 428 & 5.60 & 0.089 \\
\hline
\end{tabular}

a,bSeasonal means on the same column with different superscripts differ significantly $(p<0.05)$.

1,2 zonal means on the same column with different superscripts differ significantly $(p<0.05)$. AEZ

= Agro-ecological zones, MPB: Mayaga and peripheral Bugesera, EP: Eastern plateau, ESCB:

Eastern Savanna and Central Bugesera, SEM: standard error of the mean.

$(p<0.05)$ (Table 6). Between zones, the variation for methane emission was from 143.11 for MPB zone to $185.54 \mathrm{~g}$ for ESCB zone that had the highest $(p<0.05)$ emission. The mean emission factor $(E F)$ in the study area was $57.96 \mathrm{Kg}$ of methane/year. However, the EF varied from 51.72 for EP to $66.58 \mathrm{Kg}$ for ESCB zone. The energy loss per year in methane emission was estimated to be 3118.53, 2874.40, and 3741.99 MJ respectively for zone MPB, EP, and ESB. The yearly mean quantity of methane per unit of raw milk produced was $61.91 \mathrm{~g} \mathrm{CH}_{4} / \mathrm{L}$ of milk but it did not show any significant variation with zones. It varied from 44.92 for EP to $75.44 \mathrm{~g} \mathrm{CH}_{4} / \mathrm{L}$ of milk for MPB zone (Table 7). 
Table 4. Yearly milk yield per daily cow.

\begin{tabular}{lccc}
\hline Parameters & N & Milk (L) & SEM \\
\hline AEZ & & & \\
MPB & 60 & $771.33^{\mathrm{a}}$ & 72.95 \\
EP & 60 & $1427.1^{\mathrm{b}}$ & 71.98 \\
ESCB & 66 & $1325.20^{\mathrm{b}}$ & 95.90 \\
& & & \\
Breed & & & \\
Local & 14 & $1160.64^{1}$ & 236.99 \\
Crossbreed & 28 & $1199.61^{1}$ & 142.11 \\
Jersey & 40 & $1760.02^{2}$ & 95.23 \\
Holstein-Friesian & 104 & $953.19^{1}$ & 55.71 \\
& & & 73.2 \\
\hline
\end{tabular}

a, b Zonal means on the same column with different superscripts differ significantly $(p<0.05){ }^{1,2}$ Means of breed on the same row with different superscripts differ significantly $(p<0.05)$. AEZ = Agro-ecological zones, MPB: Mayaga and peripheral Bugesera, EP: Eastern plateau, ESCB: Eastern Savanna and Central Bugesera.

Table 5. Milk composition.

\begin{tabular}{|c|c|c|c|c|c|}
\hline \multirow{2}{*}{ Parameters } & \multirow{2}{*}{$\mathbf{N}$} & \multicolumn{4}{|c|}{ Components (\%) (SE) } \\
\hline & & Fat & Proteins & Lactose & SNF \\
\hline \multicolumn{6}{|l|}{ Season } \\
\hline Long dry & 117 & $3.79(0.166) \mathrm{a}$ & $3.17(0.037)^{a}$ & $4.77(0.055)^{a}$ & $8.69(0.092)^{a}$ \\
\hline Short rainy & 120 & $4.04(0.210)^{a}$ & $3.27(0.027)^{a}$ & $4.88(0.046)^{a}$ & $8.94(0.064)^{a}$ \\
\hline Short dry & 92 & $5.49(0.240)^{b}$ & $3.23(0.031)^{a}$ & $4.80\left(0.5052^{a}\right.$ & $8.88(0.083)^{a}$ \\
\hline Long rainy & 89 & $4.50(0.212)^{a}$ & $3.27(0.032)^{a}$ & $4.89(0.053)^{a}$ & $8.89(0.095)^{a}$ \\
\hline \multicolumn{6}{|l|}{$A E Z$} \\
\hline MPB & 107 & $4.87(0.164)^{1}$ & $3.19(0.039)^{1}$ & $4.67(0.068)^{1}$ & $8.720 .106)^{1}$ \\
\hline EP & 153 & $3.93(0.178)^{2}$ & $3.26(0.024)^{1}$ & $4.92(0.032)^{2}$ & $8.92(0.065)^{1}$ \\
\hline ESCB & 158 & $4.60(0.191)^{1}$ & $3.23(0.016)^{1}$ & $4.85(0.032)^{2}$ & $8.85(0.048)^{1}$ \\
\hline Overall mean & 418 & $4.41(0.108)$ & $3.23(0.015)$ & $4.83(0.024)$ & $8.85(0.039)$ \\
\hline
\end{tabular}

${ }^{a, b}$ Seasonal means on the same column with different superscripts differ significantly $(p<0.05) .{ }^{1,2}$ zonal means on the same column with different superscripts differ significantly $(p<0.05)$. AEZ = Agro-ecological zones, MPB: Mayaga and peripheral Bugesera, EP: Eastern plateau, ESCB: Eastern Savanna and Central Bugesera, SEM: standard error of the mean, SE: Standard error, SNF: Solid non-fat.

Table 6. Daily methane emission.

\begin{tabular}{lccc}
\hline Parameters & N & Methane $(\mathbf{g} / \mathbf{d})$ & SEM \\
\hline Season & & & \\
Long dry & 186 & $145.59^{\mathrm{a}}$ & 3.98 \\
Short rainy & 186 & $157.95 \mathrm{a}$ & 5.03 \\
Short dry & 184 & $177.36^{\mathrm{b}}$ & 4.65 \\
Long rainy & 184 & $156.19^{\mathrm{a}}$ & 3.45 \\
& & & \\
AEZ & & & 4.20 \\
MPB & 60 & $147.41^{1}$ & 4.20 \\
EP & 60 & $143.11^{1}$ & 4.07 \\
ESCB & 66 & $185.54^{2}$ & \\
Yearly mean & & & 2.40 \\
\hline
\end{tabular}

a,bSeasonal means on the same column with different superscripts differ significantly $(p<0.05)$. ${ }^{1,2}$ zonal means on the same column with different superscripts differ significantly $(p<0.05)$. g/d: gram per day, AEZ = Agroecological zones, MPB: Mayaga and peripheral Bugesera, EP: Eastern plateau, ESCB: Eastern Savanna and Central Bugesera. 
Table 7. Emission factor, energy loss, and footprint.

\begin{tabular}{lcccccccc}
\hline AEZ & MPB $(\mathbf{N}=60)$ & SEM & EP $(\mathbf{N}=60)$ & SEM & ESCB (N=66) & SEM & Overall & SEM \\
\hline $\mathrm{LW}(\mathrm{Kg})$ & 281 & 8.42 & 305 & 8.4 & 292 & 8.12 & 293 & 4.81 \\
$\mathrm{EF}: \mathrm{CH} / \mathrm{Kg}) /$ year & $54.72^{\mathrm{a}}$ & 1.27 & $51.72^{\mathrm{a}}$ & 1.49 & $66.58^{\mathrm{b}}$ & 1.70 & 57.96 & 0.99 \\
$\mathrm{CO}_{2} \mathrm{Eq}(\mathrm{Kg}) /$ year & 1368 & 6.35 & 1293 & 7.45 & 1664.50 & 8.5 & 1449 & 4.95 \\
Energy loss as $\mathrm{CH}_{4}(\mathrm{MJ}) /$ year & $3118.53^{\mathrm{a}}$ & 72.56 & $2874.40^{\mathrm{a}}$ & 82.73 & $3741.99^{\mathrm{b}}$ & 92.89 & 3255.80 & 55.21 \\
$\mathrm{CH}_{4}(\mathrm{~g} / \mathrm{L}$ of raw milk) & $75.44^{\mathrm{a}}$ & 8.73 & $44.92^{\mathrm{a}}$ & 3.53 & $68.30^{\mathrm{a}}$ & 6.46 & 61.91 & 3.72 \\
$\mathrm{CH}_{4}(\mathrm{~g} / \mathrm{L}$ of $\mathrm{FPCM})$ & $67.09^{\mathrm{a}}$ & 7.60 & $49.46^{\mathrm{a}}$ & 3.63 & $75.24^{\mathrm{a}}$ & 10.74 & 63.80 & 4.72 \\
$\mathrm{CO}_{2} \mathrm{Eq}(\mathrm{g} / \mathrm{L}$ of $\mathrm{FPCM})$ & $1677.25^{\mathrm{a}}$ & 38 & $1236.50^{\mathrm{a}}$ & 18.15 & $1881.00^{\mathrm{a}}$ & 53.70 & 1595.00 & 23.60 \\
\hline
\end{tabular}

a, bOverall means on the same row with different superscripts differ significantly $(p<0.05)$. AEZ = Agro-ecological zones, SEM: Standard error of the mean, MPB: Mayaga and peripheral Bugesera, EP: Eastern plateau, ESCB: Eastern Savanna and Central Bugesera, $\mathrm{CO}_{2}$ Eq: carbon dioxide equivalent, FPCM: fat and protein corrected milk.

\section{DISCUSSION}

\section{Nutrients supply}

The nutrients supply was lower in dry seasons. The results confirm earlier findings that showed a variation of fodder with the season in Eastern Africa, throughout sub-Saharan Africa and Rwanda (Abate et al., 1992, Renard, 1997; Klapwijk et al., 2014) where both the quantity and quality of fodder offered to cattle during the dry seasons are reported to be lower than in wet seasons. The DMI was lower in the long dry season as this season is associated with feed scarcity accompanied by poor feed digestibility, as observed in this study. The ESCB had the highest DMI because in that zone farmers usually practice croplivestock integration agriculture; hence the crop residues are more available than in other zones, especially during the dry season. The higher CP supply reported in EP zone could be explained by the quality of the forages in that zone. In EP, couch and kikuyu grasses which had a higher protein content were most widely used compared to other zones. The DMD was associated with increased protein intake and reduced ADF. The $C P$ in forages normally produces rumen degradable nitrogen that enables the rumen microbe to degrade fiber (Schwab et al., 2005). The ADF content (quantity per DM) that varied from 51.89 to $57.47 \%$ in the current study was lower than 60.0 to $68.4 \%$ and 55.9 to $64.1 \%$ reported from smallholder dairy farmers in Nandi and Nyando counties of Kenya (Goopy et al., 2018; Ndung'u et al., 2019). The digestibility was higher in the two regions because the forages used were higher in $\mathrm{CP}$ and ADF content than ones in the current study. The seasonal variation reported in this study corroborates the results reported in browse species in the Rift Valley of Ethiopia that showed an increase of DM digestibility was associated with the wet seasons (Hassen et al., 2017). The reason for the increase in DMD can be attributed to the increase of nutrient uptake, including nitrogen during the rainy season than in the dry season (Knapp et al., 2008). However, the results differ from the ones reported in Nyando and Nandi Counties of Kenya. In the two Counties, the DMD was higher in the dry season (Goopy et al., 2018;
Ndung'u et al., 2019).

The metabolizable energy supply was related to the quality and quantity of forage; hence the rainy season had the highest values. Similarly, the AEZ with high DMI had a higher ME intake. The metabolizable energy requirement for maintenance (MERM) and lactation (MERL), were lower in the long dry season due to the less live weight and comparatively less milk production. However, the highest value of MERL requirement was observed in the short-rain season. These results confirm earlier findings by Goopy et al. (2018) in Nyando County of Kenya that reported 32.7, $31.4,27.5$ and $25.7 \mathrm{MJ} /$ day for the short dry season, short wet season, long dry season and long wet season respectively for dairy cows aged of more than 2 years. However, these values were lower than $51.44 \mathrm{MJ} /$ day reported in the current study because of lower live weight. The current study had MEML lower than the $69.3 \mathrm{MJ} /$ day found in Nandi County of Kenya for mature cows (Ndung'u et al., 2019).

\section{Milk yield and composition}

The lower mean milk production was observed in the long dry season as the season is associated with feed scarcity and poor nutrient supply, manifested by the observed low protein supply during this season (Metcalf et al., 2008). EP zone had the highest daily milk production compared to others. This could be explained by the nutrients supply. The protein supply was significantly the highest of the three zones, but its metabolizable energy supply was the second. The mean season milk production that varied from 4.76 to $6.31 \mathrm{~L}$ with $5.60 \mathrm{~L}$ as yearly mean reported in the current study is similar to $5.4 \mathrm{~L}$ reported in the Eastern province of Rwanda on Ankole Longhorn x Holstein Friesian crossbred cows fed on Napier grass (Mutimura et al., 2018). However, these authors reported higher means of 7.1 and $9.0 \mathrm{~L}$ when cows were fed on basal Napier grass and Brachiaria, each combined with Desmodium, respectively. The reason is the higher protein content of these diets compared to the mean protein content of the seasonal baskets in the current study. The mean daily milk 
yield in this study was higher than 1.33 to $4.58 \mathrm{~L}$ of milk/day reported from the local-breed cow in the Southern province of Rwanda (Klapwijk et al., 2014). This could be explained by the fact that the current study used crossbreed with higher potential than the local breeds for milk production. The same reason can explain the higher mean daily milk production compared to 4 and $3.7 \mathrm{~L}$ reported in smallholder farmers in Kenya (Muinga et al., 2016; Ndung'u et al., 2019).

The milk fat content reported in this study was relatively high compared to those reported in the previous studies in Rwanda (Hirwa et al., 2017). The high fat content can be explained by the fact that the feeds in the study zones were mainly made of forage therefore high fiber content. When the feed contains a high fiber content, cellulose, the main component of the fiber, will ferment slowly and steadily, resulting in more acetate (Sutton, 1980). Acetate is the major lipogenic volatile fatty acids (VFA) and its high proportion results in elevated butterfat content. Milk fat percentage is correlated positively to rumen molar proportion of acetate and butyrate and negatively to that of propionate (Prange et al., 1978). Sutton (1980) reported that the changes in the molar proportion of propionate in the rumen estimated are responsible for 60 percent of the variations observed in milk fat content. The fat content in this study was higher than the 3.24 and $2.8 \%$ reported in local breed Inyambo and Inyambo-Fresian cross respectively (Hirwa et al., 2017). The milk fat content in this study showed a moderate variation with season and zones. The milk fat was negatively correlated to the quantity of milk between the AEZs. Other milk components did not show a significant variation. The milk protein content of $3.2 \%$ reported in the crossbreed in Rwanda by Hirwa et al. (2017) was similar to $3.23 \%$ reported in the current study. The lactose content of $2.58 \%$ reported by Hirwa et al. (2017) was much lower than that reported in the current study.

\section{Methane emission}

Without any feed additives intervention, $\mathrm{CH}_{4}$ mitigant agents nor concentrate use, the main determinant of the $\mathrm{CH}_{4}$ emission is the DMI followed by feed quality (Ellis et al., 2007; Charmley et al., 2016). This explains why the emissions were lower in the long dry seasons compared to other seasons despite its lower feed quality. The same reason comfirmed the increased emissions in the ESCB zone because of its comparatively higher DMI with less quality feeds. The emission factor (EF) factor values reported in this study were lower than $99.37 \mathrm{Kg}$ of $\mathrm{CH}_{4} /$ year for dairy cattle reported in South Africa (Moeletsi et al., 2017) because the cows were heavier and more productive than the ones in the current study. However, the values in this study $(51.72$ to $66.58 \mathrm{Kg})$ were higher than the values reported in studies carried out in Nyando and Nandi Counties of Kenya and in Ethiopia (Goopy et al., 2018; Defar et al., 2018; Ndung'u et al., 2019). In Nyando County, the mean EF values for adult females were $34.1,26.7$, and $27.1 \mathrm{Kg}$ for highlands, lowlands, and slopes topographic zones respectively (Goopy et al., 2018). The low emissions reported by these authors could be explained by the lower DMI due to the lower live weight compared to the one reported in this study. The mean live weight value in Nyando was $216.6 \mathrm{Kg}$ (Goopy et al., 2018) while it was $292.6 \mathrm{Kg}$ in this study for adult females. In Nandi County, the difference in their values was not as much different from those in this study compared to Nyando's. The reported mean value in Nandi for adult females was $50.6 \mathrm{Kg}$ in three agro-ecological zones (Ndung'U et al., 2019), which is a bit lower than $57.96 \mathrm{Kg}$ reported in this study. The mean live weight $(306.9 \mathrm{Kg})$ in Nandi was similar to the one reported in this study. However, the lower emission can be explained by the lower DMI in that region.

The present EFs were higher than the default IPPC value of $41 \mathrm{Kg}$ from developing countries in African, Middle East and other tropical regions livestock EFs using Tier I approach (IPCC, 2006) and higher than the average figure of $32 \mathrm{Kg} \mathrm{CH}_{4}$ per Tropical Livestock Unit (TLU ) per year for African ruminants (Herrero et al., 2008). The IPPC predicts a mean live weight of $200 \mathrm{Kg}$ for cattle in these regions which is lower than $292.6 \mathrm{Kg}$ in this study, hence the lower EFs. Lower methane emission per unit gram milk produced (Carbon footprint) was observed in the EP zone. The results showed the highest milk production in that zone despite the DMI that was not the highest. This suggests that the Carbon footprint can be reduced by increased milk production efficiency, which can be achieved through an increased supply of digestible feed and main nutrients like proteins, as observed in the EP zone. This was confirmed in a study carried out in Sweden by Danielsson et al. (2017) who worked on cows in an intensive production system. The authors reported a value of $8.04 \mathrm{~g}$ as $\mathrm{CH}_{4}$ emission per Litre of energy corrected milk. The value is much lower than $63.80 \mathrm{~g}$ reported in the current study, despite the higher estimated annual methane emission of $106.22 \mathrm{Kg}$ for the Swedish study. Danielsson et al. (2017) found a higher daily milk production of $35.2 \mathrm{~L}$ for $23.8 \mathrm{Kg} \mathrm{DMl}$ compared to $5.6 \mathrm{~L}$ and $7.92 \mathrm{kgs}$ for milk and DMl respectively in the current study. Dini et al. (2012) also reported a lower relative $\mathrm{CH}_{4}$ emission with 18.6 to $20.6 \mathrm{~g} \mathrm{CH}_{4} / \mathrm{Kg}$ of fat corrected milk in improved dairy cows on pastures. With lower DMI in Nandi County of Kenya, the $\mathrm{CH}_{4}$ emission per milk production was almost half the value reported in the current study. The milk production varied from 3.7 to $5.3 \mathrm{~L}$ for upper midlands and lower highlands, respectively with 34.43 and 25.47 corresponding values of $\mathrm{CH}_{4} \mathrm{~g}$ per one liter of milk (Ndung'U et al., 2019).

The enteric methane emission represents a loss of feed gross energy. This suggests that the productivity of the cows can be increased through enteric methane emission reduction. Available literature shows that 2 to $12 \%$ of feed 
gross energy is lost as combustible gases mainly as methane and hydrogen (Johnson and Johnson, 1995), which contribute to global warming. However, for a full carbon footprint evaluation, there is a need to consider all the sources of methane at the farm level or by using Life Cycle Assessment approach (FAO, 2010).

\section{Conclusion}

The dry matter intake (DMI) and nutrients supply were lower in dry seasons. The ESCB zone that practices more crop-livestock integration agriculture had the highest DMI because of the relatively high availability of crop residues. In EP zone, a higher CP supply was reported due to the comparative high-quality forages. EP zone had the highest daily milk production compared to others as it has a comparatively higher protein supply. The milk fat content showed a moderate variation with season and zones. The long dry season had a lower methane emission as it is associated with lower DMI. The ESCB with a comparatively higher DMI and less quality feeds had a higher methane emission. The present EFs were higher than the default IPPC value using Tier I approach due to a lower predicted live weight of cows in the Intergovernmental Panel on Climate Change (IPCC) estimates. The lower emission per unit $\mathrm{g}$ milk production (Carbon footprint) was observed in the EP zone that had a higher daily milk production per cow. This suggests that the Carbon footprint can be reduced by increased milk production efficiency through high-quality feed and cows. This study only considered animal feeds as a source of methane emission. However, all the sources of methane at the farm level should be considered for appropriate mitigation strategies.

\section{CONFLICTS OF INTEREST}

The authors declare that they have no conflict of interest.

\section{ACKNOWLEDGMENTS}

The authors would like to acknowledge the dairy farmers who participated in this study, alongside the government of Rwanda for permitting us to conduct the study. Furthermore, we would like to pass our sincere gratitude to BHEARD for proving the financial support to carry out this study.

\section{REFERENCES}

Abate, A., Dzowela, B. H., \& Kategile, J. A. (1992) Intensive animal feeding practices for optimum feed utilization. In: Kategile, J. A., \& Mubi, S. (eds.). Future of livestock industries in East and Southern Africa (pp. 9-19). Proceedings, Workshop held at Kadoma Ranch Hotel, Zimbabwe, July 1992.
Addis Ababa, Ethiopia: International Livestock Centre for Africa (ILCA).

Arriola, A. S. I., Knapp, J. R., \& Hanigan, M. D. (2014). Invited review: Current representation and future trends of predicting amino acid utilization in the lactating dairy cow. Journal of Dairy Science, 97(7), 4000-4017.

Ayabagabo, J. D., Migwi, P. K., \& Onjoro, P. A. (2020). Seasonal variations in types and nutrient concentrations of feedstuffs for dairy cattle in smallholder farmers in the Eastern Province of Rwanda. Indian Journal of Animal Nutrition, 37(3),195-205.

Brun-Lafleur, L., Delaby, L., Husson, F., \& Faverdin, P. (2010). Predicting energy $\times$ protein interaction on milk yield and milk composition in dairy cows. Journal of Dairy Science, 93(9), 4128-4143.

Charmley, E., Williams, S. R. O., Moate, P. J., Hegarty, R. S., Herd, R. M., Oddy, V. H., Reyenga, P., Staunton, K. M., Anderson, A., \& Hannah, M. C. (2016). A universal equation to predict methane production of forage-fed cattle in Australia. Animal Production Science, 56(3), 169-180.

Commonwealth Scientific and Industrial Research Organisation (CSIRO) (2007). Nutrient requirements of domesticated ruminants. CSIRO, Collingwood (Australia). 270p.

Danielsson, R., Dicksved, J., Sun, L., Gonda, H., Müller, B., Schnürer, A., \& Bertilsson, J. (2017). Methane production in dairy cows correlates with rumen methanogenic and bacterial community structure. Frontiers in microbiology, 8, 226.

Defar, G., Mengistu, A., \& Berhane, G. (2018). Estimation of livestock methane emissions in the extensive crop-livestock farming areas of Bale highland, Oromia, Ethiopia. European Journal of Applied Sciences, 10(4), 89-98.

Dingwell, R. T., Wallace, M. M., McLaren, C. J., Leslie, C. F., \& Leslie, K. E. (2006). An evaluation of two indirect methods of estimating body weight in Holstein calves and heifers. Journal of Dairy Science, 89(10), 3992-3998.

Dini, Y., Gere, J., Briano, C., Manetti, M., Juliarena, P., Picasso, V., Gratton, R., \& Astigarraga, L. (2012). Methane emission and milk production of dairy cows grazing pastures rich in legumes or rich in grasses in Uruguay. Animals, 2(2), 288-300.

Edmonson, A. J., Lean, I. J., Weaver, L. D., Farver, T., \& Webster, G. (1989). A Body condition scoring chart for Holstein dairy cows. Journal of Dairy Science, 72(1), 68-78.

Ellis, J. L., Kebreab, E., Odongo, N. E., McBride, B. W., Okine, E. K., \& France, J. (2007). Prediction of methane production from dairy and beef cattle. Journal of Dairy Science, 90(7), 3456-3466.

Environmental Protection Agency (EPA) (2014). Interactive units converter. Environmental Protection Agency. Retrieved from https://www.epa.gov/cmop/units-converter\#kilograms.

Food and Agriculture Organization (FAO) (2010). Greenhouse gas emissions from the dairy sector. A life cycle assessment. A comprehensive study on GHG emissions from the global dairy sector. Food and Agriculture Organization of the United Nations, Rome, Italy. Retrieved from http://www.fao.org/3/k7930e/k7930e00.pdf

Goopy, J. P., Onyango, A. A., Dickhoefer, U., \& Butterbach-Bahl, K. (2018). A new approach for improving emission factors for enteric methane emissions of cattle in smallholder systems of East Africa-Results for Nyando, Western Kenya. Agricultural Systems, 161, 72-80.

Hammond, K. J., Humphries, D. J., Crompton, L. A., Kirton, P., Green, C., \& Reynolds, C. K. (2013). Methane emissions from growing dairy heifers estimated using an automated head chamber (GreenFeed) compared to respiration chambers or SF6 techniques. Advances in Animal Biosciences, 4(2), 391. 
Hassen, A., Tessema, Z. K. \& Tolera, A. (2017). Seasonal variations in chemical composition, in vitro digestibility and ruminal degradation of browse species in the Rift Valley of Ethiopia. Livestock Research for Rural Development, 29, Article Number 112. Retrieved May 17, 2020, from http://www.Irrd.org/Irrd29/6/tess29112.htm.

Herrero, M., Thornton, P. K., Kruska, R., \& Reid, R. S. (2008). Systems dynamics and the spatial distribution of methane emissions from African domestic ruminants to 2030. Agriculture, Ecosystems and Environment, 126(1-2), 122-137.

Hirwa, C. D'A., Kugonza, D. R., Murekezi, T., Rwemarika, J. D., Kayitesi, A., Musemakweri, A., Shabayiro, J. P., Shumbusho, F., Manzi, M., \& Safari, T. (2017). Management and phenotypic features of indigenous cattle in Rwanda. International Journal of Livestock Production, 8(7), 95-112.

Intergovernmental Panel on Climate Change (IPCC) (2007). Climate change 2007: The physical science basis. Contribution of Working Group I to the Fourth Assessment Report of the Intergovernmental Panel on Climate Change. Solomon, S., Qin, D., Manning, M., Chen, Z., Marquis, M., Averyt, K. B., Tignor, M., \& Miller, H. L. (eds.). Cambridge University Press, Cambridge, United Kingdom and New York, NY, USA, 996p. Retrieved March 15, 2019, from https://www.ipcc.ch/site/assets/uploads/2018/05/ar4_wg1_full report-1.pdf.

Jen̄sen, C., Østergaard, S., Schei, I., Bertilsson, J., \& Weisbjerg, M. R. (2015). A meta-analysis of milk production responses to increased net energy intake in Scandinavian dairy cows. Livestock Science, 175, 59-69.

Johnson, K. A., \& Johnson, D. E. (1995). Methane emissions from cattle. Journal of Animal Science, 73(8), 2483-2492.

Klapwijk, C. J., Bucagu, C., van Wijk, M. T., Udo, H. M. J., Vanlauwe, B., Munyanziza, E., \& Giller, K. E. (2014). The 'one cow per poor family'programme: Current and potential fodder availability within smallholder farming systems in southwest Rwanda. Agricultural Systems, 131, 11-22.

Knapp, A. K., Beier, C., Briske, D. D., Classen, A. T., Luo, Y., Reichstein, M., Smith, M. D., Smith, S. D., Bell, J. E., Fay, P. A., \& Weng, E. (2008). Consequences of more extreme precipitation regimes for terrestrial ecosystems. Bioscience, 58(9), 811-821.

Loh, Z., Chen, D., Bai, M., Naylor, T., Griffith, D., Hill, J., Denmead, T., McGinn, S., \& Edis, R. (2008). Measurement of greenhouse gas emissions from Australian feedlot beef production using open-path spectroscopy and atmospheric dispersion modelling. Australian Journal of Experimental Agriculture, 48(2), 244-247.

Metcalf, J. A., Mansbridge, R. J., Blake,J. S., Oldham,J. D., \& Newbold, J. R. (2008). The efficiency of conversion of metabolisable protein into milk true protein over a range of metabolisable protein intakes. Animal, 2(8),1193-1202.

Moeletsi, M. E., Tongwane, M. I., \& Tsubo, M. (2017). Enteric methane emissions estimate for livestock in South Africa for 1990-2014. Atmosphere, 8(5), 69.

Moraes, L. E., Strathe, A. B., Fadel, J. G., Casper, D. P., \& Kebreab, E. (2014). Prediction of enteric methane emissions from cattle. Global Change Biology, 20(7), 2140-2148.

Muinga, R. W., Njunie, M. N., Gatheru, M., \& Njarui, D. M. G. (2016). The effects of Brachiaria grass cultivars on lactation performance of dairy cattle in Kenya. Climate smart Brachiaria grasses for improving livestock production in East Africa Kenya experience. Proceedings of the Workshop Held in Naivasha, Kenya, 14 - 15 September, 2016, Pp. 229-237. Kenya Agricultural and Livestock Research Organization
(KALRO).

Mutimura, M., Ebong, C., Rao, I. M., \& Nsahlai, I. V. (2015). Nutritional values of available ruminant feed resources in smallholder dairy farms in Rwanda. Tropical Animal Health and Production, 47(6), 1131-1137.

Mutimura, M., Ebong, C., Rao, I. M., \& Nsahlai, I. V. (2018). Effects of supplementation of Brachiaria brizantha cv. Piatá and Napier grass with Desmodium distortum on feed intake, digesta kinetics and milk production in crossbred dairy cows. Animal Nutrition, 4(2), 222-227.

National Institute of Statistics of Rwanda (NISR) (2016). Statistical yearbook, 2016 edition (SYB2016). In: National Institute of Statistics of Rwanda (NISR). Retrieved April 25, 2019,

from https://www.statistics.gov.rw/file/5077/download?token=KKp3 ISIv.

National Research Council (NRC) (2001). Nutrient requirements of dairy cattle: Seventh Revised Edition, 2001. Washington, DC: The National Academies Press.

Ndung'U, P. W., Bebe, B. O., Ondiek, J. O., Butterbach-Bahl, K., Merbold, L., \& Goopy, J. P. (2019). Improved region-specific emission factors for enteric methane emissions from cattle in smallholder mixed crop: Livestock systems of Nandi County, Kenya. Animal Production Science, 59(6), 1136-1146.

Oddy, V. H., Robards, G. E., \& Low, S. G. (1983). Prediction of in vivo dry matter digestibility from the fibre and nitrogen content of a feed. In Feed information and animal production: proceedings of the second symposium of the International Network of Feed Information Centres/edited by GE Robards and RG Packham. Farnham Royal, Slough [Buckingham]: Commonwealth Agricultural Bureaux, c1983.

Paul, B. K., Frelat, R., Birnholz, C., Ebong, C., Gahigi, A., Groot, J. C., Herrero, M., Kagabo, D. M., Notenbaert, A., Vanlauwe, B., \& Van Wijk, M. T. (2018). Agricultural intensification scenarios, household food availability and greenhouse gas emissions in Rwanda: Ex-ante impacts and tradeoffs. Agricultural Systems, 163(6), 16-26.

Prange, R. W., Davis, C. L., \& Clark, J. H. (1978). Propionate production in the rumen of Holstein Steers fed either a control or monensin supplemented diet. Journal of Animal Science, 46(4), 1120-1124.

Renard, C. (1997). Crop residues in sustainable mixed crop/ livestock farming systems. CAB International, Wallingford, UK.

Rwanda Governance Board (RGB) (2018). Assessing the Girinka programme. Girinka report. Retrieved 29 April 29, 2021,

from http://rgb.rw/fileadmin/Key_documents/HGS/GIRINKA_REPO RT_2018.pdf

Schwäb, C. G., Huhtanen, P., Hunt, C. W., \& Hvelplund, T. (2005). Nitrogen requirements of cattle. In: Pfeffer, E., \& Hristov, A. N. (eds.). Nitrogen and Phosphorus Nutrition of Cattle and Environment (pp. 13-70). CAB International, Wallingford, UK.

Sutton J. D (1980). Influence of nutritional factors on the yield and content of milk fat: Dietary components other than fat [dairy cattle; rumen fermentation; glucose supply, amino acid supply]. International Dairy Federation, 125-126. Retrieved from search/search.do?recordID=BE19810638424.

Tomasula, P. M., \& Nutter, D. W. (2011). Mitigation of greenhouse gas emissions in the production of fluid milk. Advances in food and nutrition research, 62, 41-88.

Torell, R., Bruce, B., Kvasnicka, B., \& Conley, K. (2003). Methods of determining age of cattle. Cattle Producer's Library: CL712, 
1-3. University of Nevada, Reno, NV.

Tubiello, F. N., Salvatore, M., Cóndor Golec, R. D., Ferrara, A., Rossi, S., Biancalani, R., Federici, S., Jacobs, H., \& Flammini, A. (2014). Agriculture, forestry and other land use emissions by sources and removals by sinks. ESS Working Paper No.2, (pp. 4-89). Rome, Italy.
Yan, T., Mayne, C. S., Patterson, D. C., \& Agnew, R. E. (2009). Prediction of body weight and empty body composition using body size measurements in lactating dairy cows. Livestock Science, 124(1-3), 233-241. 